2019 Global Fashion Management Conference at Paris Proceedings: 810-811 (July 2019) https://doi.org/10.15444/GFMC2019.08.03

\title{
ANALYZING THE IMPACT OF MASSCLUSIVITY CAMPAIGNS ON LUXURY AND MASS-MARKET FASHION BRANDS
}

\author{
Joana Fonseca dos Santos, Instituto Universitário de Lisboa (ISCTE-IUL), Portugal \\ Ricardo Godinho Bilro, Instituto Universitário de Lisboa (ISCTE-IUL), Business \\ Research Unit (BRU-IUL), Portugal ${ }^{1}$ \\ Sandra Maria Correia Loureiro, Instituto Universitário de Lisboa (ISCTE-IUL), \\ Business Research Unit (BRU-IUL), Portugal
}

\begin{abstract}
The current research aims to explore the impact of Massclusivity campaigns (massive and exclusive) (Brogi et al., 2009; Silverstein \& Fiske, 2003) on the brand love of online brand communities. In this sense, this study comprises (i) the analysis of the meaning and perception of luxury, (ii) the marketplace associated to luxury - with a focus on the fashion consumption segment, (iii) and the impact of trends such as digital luxury and Massclusivity. We intend to explore the dynamics of the selected market based on the core of relationship marketing concepts, brand love, brand communities and consumerbrand relationship.

Currently, the world is facing a democratization of luxury (Kapferer \& Valette-Florence, 2016; Truong, McColl \& Kitchen, 2009), and it became critical to understand how it affects the traditional luxury consumers. Formerly, luxury was all about ostentation, status seeking and social approval and, as a virtue of that, its customers demanded exclusivity and exceptional quality (Silverstein \& Fiske, 2003). Globalization has allowed many luxury fashion magazines to be available worldwide, and also made information exchange possible. Moreover, the digital era offers a set of benefits to brands, and one of these benefits is the ability to offer content in distinct platforms (Okonkwo, 2009). By using the digital environment, masses started to relate with certain lifestyles (connected to luxury consumption) and start craving accessible luxury products (Brun \& Castelli, 2013). So, the research questions that emerge in this study are: (i) does a Massclusivity campaign impacts consumers' brand love towards the brand? (ii) how does massive luxury affect the love or hate of the luxury fashion brands' online communities?
\end{abstract}

A netnography analysis (Kozinets, 2002; Brown, Kozinets \& Sherry Jr., 2003) was developed concerning the interactions between the selected brands - a luxury fashion brand, Gucci, and a mass market fashion brand, H\&M - and their respective online brand communities on Facebook (a social networking platform), during a specific period of time defined according to the launch of Massclusivity campaigns by each of these brands. Concerning the sample, we collect a total of 12,842 interactions $(10,691$ interactions for Gucci and 2,151 for H\&M). We analyze Gucci community members' interactions from March 2017 to March 2018. Concerning H\&M, we consider the interactions from July 2017 to March 2018.

\footnotetext{
${ }^{1}$ bilro.ricardo@gmail.com
} 
When comparing the results achieved for both brands, Gucci reveals the highest polarity average associated to its members' interactions. When comparing the interactions analyzed from H\&M consumers, Gucci's interactions had more positive sentiments. Consequently, we induce that the massive luxury campaigns had more positive results for the luxury brand that promote a massclusivity collection (Gucci) than for H\&M who developed a co-branding massclusivity campaign.

This research provides valuable insights not only for luxury brands but also for the fashion market in general. In this research we were able to put in evidence that despite the low impact on brand love of online brand community members, the development of massclusivity campaigns have several impacts identified, such as: (i) generate awareness towards the brand, (ii) increases consumers' engagement on social network platforms, and (iii) promote communities' expansion. We may argue that these consequences are directly related to the curiosity that these marketing strategies generate towards the brands, which may be considered powerful to luxury brands who intend to diversify their audience and become competitive among a traditional sector.

Keywords: massclusivity, brand love, online brand communities

Acknowledge: This work was supported by Fundação para a Ciência e a Tecnologia, grant UID/GES/00315/2019

\section{References}

Brogi, S., Calabrese, A., Campisi, D., Capece, G., Costa, R., \& Pillo F. (2013). The Effects of Online Brand Communities on Brand Equity in the Luxury Fashion Industry. International Journal of Engineering Business Management, 5(32), 19.

Brown, S., Kozinets, R. V., \& Sherry Jr., J. F. (2003). Teaching Old Brands New Tricks: Retro Branding and the Revival of Brand Meaning. Journal of Marketing, 67(3), 19-33.

Brun, A., \& Castelli, C. (2013). The nature of luxury: a consumer perspective. International Journal of Retail \& Distribution Management, 41(11/12), 823 847.

Kapferer, J., \& Valette-Florence, P. (2016). Beyond rarity: the paths of luxury desire. How luxury brands grow yet remain desirable. Journal of Product \& Brand Management, 25(2), $120-133$.

Kozinets, R. V. (2002). The Field Behind the Screen: Using Netnography for Marketing Research in Online Communities. Journal of Marketing Research, 39(1), 61-72.

Okonkwo, U. (2009). Sustaining the luxury brand on the Internet. Journal of Brand Management, 16(5/6), 302-310.

Silverstein, M. J., \& Fiske, N. (2003). Luxury for the Masses. Harvard Business Review, 81(4), 48-57.

Truong, Y., McColl, R., \& Kitchen, P. J. (2009). New luxury brand positioning and the emergence of masstige brands. Journal of Brand Management, 16(5-6), 375-382. 